\title{
Quantitative Analysis of Oil Yield and Its Components in Newly Developed Hybrids of Sunflower (Helianthus annuus L.)
}

\author{
S.M. Supriya ${ }^{1 *}$, Vikas V. Kulkarni ${ }^{2}$, C.N. Ranganatha ${ }^{1}$ and P.G. Suresha ${ }^{1}$ \\ ${ }^{1}$ Department of Genetics and Plant Breeding, University of Agricultural Sciences, \\ Raichur-584104, Karnataka, India \\ ${ }^{2}$ AICRP on Sunflower, MARS, University of Agricultural Sciences, Raichur-584104, \\ Karnataka, India \\ *Corresponding author
}

\author{
A B S T R A C T
}

Keywords

Sunflower,

Genetic

variability,

Correlation and

path analysis.

Article Info

Accepted:

26 June 2017

Available Online:

10 August 2017
Increasing seed yield and oil content is one of the most important goals in sunflower (Helianthus annuus L.) breeding programs. The aim of any plant breeder includes selection from natural population or artificially developed for one or several characters. In the present investigation, twenty sunflower hybrids were evaluated for various parameters under field conditions to estimate genetic parameters, correlation coefficient and path analysis. Analysis of variance and mean performance for yield and its components revealed significant differences among all the genotypes for all the characters. Results revealed highly significant differences among all the hybrids. Higher PCV and GCV were obtained for seed yield per plant followed by head diameter and test weight. Moderate PCV and GCV were obtained for the characters viz., plant height, volume weight and oil content, while low PCV and GCV were observed for days to 50\% maturity and days to $50 \%$ flowering High value of heritability coupled with the high genetic advance was estimated for plant height, test weight, seed yield per plant, volume weight and head diameter, high heritability coupled with moderate genetic advance was recorded for days to 50 per cent flowering and oil content indicated additive gene action controlling these traits. Highly significant positive correlation was estimated between seed yield per plant with plant height, volume weight and head diameter and significant positive association with test weight but the association between seed yield and days to maturity was negative and low.

\section{Introduction}

Sunflower (Helianthus annuus L.) is an important crop, primarily grown for vegetable oil which is used for human consumption, but also as a raw material in industry (Mijić et al., 2009). The main objective of any plant breeder includes the highest seed yield and oil content in any oilseed crop especially in sunflower (Vrânceanu et al., 2005). The success of breeding programs primarily depends on the variation present for yield and yield components traits as well as nature of initial material (Nehru and Manjunath, 2003). Seed yield in sunflower is a complex quantitative trait controlled by large number of genes and is highly influenced by environmental, morphological and physiological properties. Correlation studies between yield and its component traits helps to decide the indirect selection using yield components traits to improve seed yield of 
sunflower (Fick et al., 1974). On the other side, the seed yield is a function of genetic potential of the variety, external conditions in which the crop is grown, applied technology and the interaction of all these factors (Abad et al., 2013). Sunflower seed yield, like other crops, is a function of many traits which have interrelation among them and affect the grain yield directly or indirectly.

Sunflower breeders intend to achieve the highest grain yield and oil content, through the best expression of heterosis (Vrânceanu, 2000; Vrânceanu et al., 2005). The breeding strategies are mainly oriented toward these two traits. In order to apply an optimum breeding strategy for targeted quantitative traits, a genetic analysis of those traits needs to be performed (Haş, 1999; Nistor et al., 2005). Heritability represents the ratio between genetic and all factors (including non-genetic ones) that influence the variability (Bernardo, 2002).

The higher ratio of the genetic component in phenotypic expression of a certain trait, the higher is the heritability, and selection for these traits can be performed in earlier generations in field trials set up at a smaller number of locations, years and replications. Heritability accompanied with an estimation of genetic gain is more useful than heritability alone in accurate prediction of the selection effects (Johnson et al., 1955). Besides coefficients of variability and heritability it is important to know the relationship between the analyzed traits.

It is important to estimate simple correlation coefficients, but also the direct and indirect effects of investigated traits on characters that represent selection aims described through path coefficient analysis. Path coefficient analysis has an advantage over estimation of simple correlation coefficients because it allows partitioning of the correlation coefficient into its components. These components are: 1) the path coefficient (or standardized partial regression coefficient) that measures the direct effect of a predictor variable upon its response variable; and 2) the indirect effect(s) of a predictor variable on the response variable through the predictor variables (Dewey and Lu, 1959).

The purpose of this study was to estimate phenotypic and genotypic coefficients of variation, heritability, correlations and path coefficients between important agronomic traits and oil yield in twenty-three sunflower hybrids. The results of this study will be useful for implementing a more efficient breeding strategy.

\section{Materials and Methods}

The experiment consist 23 sunflower hybrids sown in randomized complete block design (RBD) with three replications at MARS, Raichur during Kharif, 2014. Each hybrid was raised in two rows of $3 \mathrm{~m}$ length with spacing of $60 \times 30 \mathrm{~cm}$. Recommended agronomic practices were followed to raise good crop. Observations were recorded on days to $50 \%$ flowering, plant height $(\mathrm{cm})$, head diameter $(\mathrm{cm})$, days to maturity, test weight $(\mathrm{g})$, volume weight, seed yield per plant $(\mathrm{g})$ and oil content $(\%)$. The data were recorded on five randomly selected plants in each entry in each replication. The analysis of variance, coefficient of variation was calculated as per Burton and Devane (1953). Heritability in broad sense and genetic advance were calculated as per Hanson (1956) and Johnson et al., (1955), respectively. The linear correlation coefficient is estimated between seed yield and its component traits using 23 sunflower hybrids (Singh and Chaudhary, 1985). The significance of genotypic correlation coefficients was tested with the help of standard errors as suggested by Reeve and Rao (1981). 


\section{Results and Discussion}

The analysis of variance revealed highly significant variations among the hybrids for all the characters studied (Table 1). This indicates that there is enough variability in the present material. The phenotypic variance was partitioned into genotypic and environmental variances for a clear understanding of the pattern of variations.

The objective any plant breeder includes selection from natural population or artificially developed for one or several characters. The estimate of phenotypic and genotypic correlations among the characters is useful in planning the selection strategies (Nehru and Manjunath, 2003). Various kinds of associations have been reported in sunflower. Correlation coefficient measures the magnitude and direction of association among characters.

Correlation coefficient between characters assumes its importance due to genetic causes of correlation through pleiotropic actions of genes, linkage, improvement brought by selection through related characters and natural selection as concluded by Senevirtane (2005) and Kaya et al., (2007) Simultaneous improvement in two or more characters is possible when positive correlations are observed. Whereas, negative associations need to be compromised between desirable characters. Correlation coefficient helps the breeder in determining the relative importance of yield components for indirect selection for yield. Understanding importance for making the best use of these relationships for selection.

The mean value for days to fifty per cent flowering was ranged between 63-69 days. The cross (PM-20 $\times$ PM-38) was early for $50 \%$ flowering with 56 days followed by cross PM-18 x PM-34, PM-40 x PM-19 and
PM-16 x PM-37 with 59 days to days to fifty per cent flowering (Table 2). Among them only one hybrid (PM-20 $\times$ PM-38) was early in maturing compared to other hybrids which took 89 days for maturity. High heritability (89.7\% and $70.3 \%$ ) coupled with low genetic advance as per cent of mean $(10.3 \%$ and $3.7 \%$ ) was observed for days to $50 \%$ flowering and days to maturity, respectively (Table 3). Days to $50 \%$ flowering and days to maturity exhibited significant positive correlation with test weight and oil content whereas it was negative with seed yield (Tables 4 and 5). These findings are in accordance with the reports of Gangappa and Virupakshappa (1994), Senevirtane (2005), Kaya et al., (2007) and Shah et al., (2014).

\section{Plant height (cm)}

The average plant height for 23 crosses was $136 \mathrm{~cm}$. The cross (PM-10×PM-35) was dwarf $(93 \mathrm{~cm})$ followed by cross PM-22 x PM-36 with $98 \mathrm{~cm}$ of plant height. Estimates of PCV and GCV were found to be medium with the values of 15.9 per cent and 15.7 per cent, respectively and there was narrow difference between them. Plant height exhibited highly significant positive correlation with head diameter (0.5555, $0.6419)$, test weight $(0.4133,0.4299)$, volume weight $(0.4482,0.4657)$ and seed yield per plant $(0.6449,0.7122)$ both at phenotypic and genotypic level (Tables 4 and 5). Similar findings were made by Vanisree et al., (1988), Chidambaram and Sundaresan (1990), Uttam et al., (2006), Kaya et al., (2007) and Supriya et al., (2016).

The positive and significant correlation observed between plant height and seed yield per plant is justifiable. Tall plant supporting many leaves could increase total biomass production through increased carbon fixation which resultantly partitioned to reproductive organ formation. 


\section{Head diameter $(\mathrm{cm})$}

Head or capitulum diameter is an important yield contributing character attracting attention of the workers for better head size. The estimate of PCV was high and GCV was medium with the values of 24.2 per cent and 21.2 per cent, respectively. High heritability $(76.6 \%)$ coupled with high genetic advance as per cent of mean $(38.2 \%)$ was observed for this character (Table 3 ).

Head diameter exhibited significant positive correlation with plant height $(0.5555,0.6419)$, test weight $(0.5217,0.5931)$, volume weight $(0.4257,0.4877)$ and seed yield per plant $(0.3827,0.4917)$ both at phenotypic and genotypic level (Tables 4 and 5). These results were in accordance with Gangappa and Virupakshappa (1994) and Uttam et al., (2006).

\section{Test weight (g) and volume weight (g)}

The 100 seed weight of a genotype serves as an indicator of seed yield as it is an important character contributing to yield. Calyak and Emiroglu (1984) concluded that breeding for high test weight is an important character in development of superior inbred lines, which may be used for high yielding hybrid development. Test weight should be given more priority in breeding programmes for high yield.

Estimates of PCV and GCV were found to be high with the values 22.4, 21.7 and 14.1, 13.7 per cent, respectively with narrow difference between them. High heritability $(94.2 \%$ and 94.3\%)) coupled with high genetic advance (43.5\%) and moderate genetic advance as per cent of mean was observed for test weight and volume weight respectively (Table 3 ).

Table.1 ANOVA for eight characters in 23 hybrids of sunflower

\begin{tabular}{|c|c|c|c|c|c|c|c|c|c|c|}
\hline \multirow[b]{2}{*}{$\begin{array}{l}\text { Sl. } \\
\text { No }\end{array}$} & \multirow[b]{2}{*}{$\begin{array}{c}\text { Source } \\
\text { of } \\
\text { variatio } \\
\text { n }\end{array}$} & \multirow[b]{2}{*}{$\begin{array}{l}\text { D } \\
\text { f }\end{array}$} & \multicolumn{8}{|c|}{ Mean Sum of Squares } \\
\hline & & & $\begin{array}{c}\text { Days to } \\
50 \% \\
\text { floweri } \\
\text { ng }\end{array}$ & $\begin{array}{c}\text { Plant } \\
\text { height } \\
\text { (cm) }\end{array}$ & $\begin{array}{c}\text { Head } \\
\text { diamet } \\
\text { er }(\mathrm{cm})\end{array}$ & $\begin{array}{c}\text { Days } \\
\text { to } \\
\text { maturi } \\
\text { ty }\end{array}$ & $\begin{array}{r}\text { Test } \\
\text { weig } \\
\text { ht }(\mathrm{g})\end{array}$ & $\begin{array}{c}\text { Volume } \\
\text { weight } \\
\text { (g/100 } \\
\text { ml) }\end{array}$ & $\begin{array}{c}\text { Seed } \\
\text { yield/ } \\
\text { Plant } \\
(\mathrm{g})\end{array}$ & $\begin{array}{c}\text { Oil } \\
\text { conte } \\
\text { nt } \\
(\%)\end{array}$ \\
\hline 1 & $\begin{array}{l}\text { Genotyp } \\
\mathrm{e}\end{array}$ & $\begin{array}{l}2 \\
2 \\
\end{array}$ & $34.77 *$ & $\begin{array}{c}1389.4 \\
0 *\end{array}$ & $44.10^{*}$ & $13.45^{*}$ & $3.03^{*}$ & $65.94 *$ & $\begin{array}{c}122.9 \\
7 * \\
\end{array}$ & $\begin{array}{c}47.52 \\
*\end{array}$ \\
\hline 2 & $\begin{array}{l}\text { Replicati } \\
\text { on }\end{array}$ & 2 & 1.84 & 8.10 & 13.04 & 0.10 & 0.05 & 3.91 & 4.62 & 1.39 \\
\hline 3 & Error & $\begin{array}{l}4 \\
4\end{array}$ & 1.27 & 8.34 & 4.07 & 1.66 & 0.06 & 1.29 & 6.66 & 2.18 \\
\hline 4 & S.Em \pm & - & 0.65 & 1.66 & 1.16 & 0.74 & 0.14 & 0.65 & 1.49 & 0.85 \\
\hline 5 & $\begin{array}{l}\text { CD at } \\
(5 \%)\end{array}$ & - & 1.86 & 4.75 & 3.32 & 2.12 & 0.40 & 1.87 & 4.24 & 2.43 \\
\hline
\end{tabular}

$*, * *$-indicates significance at $5 \%$ and $1 \%$ level respectively 
Table.2 Mean performance of hybrids for eight quantitative characters in sunflower

\begin{tabular}{|c|c|c|c|c|c|c|c|c|c|}
\hline $\begin{array}{l}\text { Sl. } \\
\text { No. }\end{array}$ & Crosses & $\begin{array}{c}\text { Days to } \\
50 \% \\
\text { flowering } \\
\end{array}$ & $\begin{array}{c}\text { Plant } \\
\text { height } \\
(\mathbf{c m})\end{array}$ & $\begin{array}{c}\text { Head } \\
\text { diameter } \\
(\mathrm{cm})\end{array}$ & $\begin{array}{l}\text { Days to } \\
\text { maturity }\end{array}$ & $\begin{array}{c}\text { Test } \\
\text { weight } \\
\text { (g) }\end{array}$ & $\begin{array}{c}\text { Volume } \\
\text { weight } \\
(\mathrm{g} / 100 \mathrm{ml}) \\
\end{array}$ & $\begin{array}{c}\text { Seed } \\
\text { yield/ } \\
\text { Plant (g) } \\
\end{array}$ & $\begin{array}{c}\text { Oil } \\
\text { content } \\
(\%)\end{array}$ \\
\hline 1 & PM-16×PM-38 & 64 & 167 & 23 & 91 & 4.7 & 38.0 & 33.58 & 36.2 \\
\hline 2 & PM-17×PM-35 & 62 & 153 & 14 & 93 & 4.0 & 33.6 & 29.27 & 36.1 \\
\hline 3 & PM-20×PM-35 & 68 & 140 & 19 & 95 & 3.8 & 33.6 & 15.40 & 35.8 \\
\hline 4 & PM-34×-PM-23 & 64 & 110 & 19 & 94 & 4.0 & 33.9 & 17.67 & 36.2 \\
\hline 5 & PM-28×PM-12 & 69 & 166 & 25 & 95 & 5.7 & 32.9 & 21.27 & 41.0 \\
\hline 6 & PM-18×PM-34 & 59 & 141 & 21 & 92 & 5.0 & 35.0 & 24.29 & 40.3 \\
\hline 7 & PM-34×PM-18 & 61 & 132 & 22 & 92 & 5.1 & 36.1 & 22.08 & 36.3 \\
\hline 8 & PM-40×PM-19 & 59 & 161 & 22 & 91 & 5.7 & 39.8 & 24.39 & 42.5 \\
\hline 9 & PM-14×PM-36 & 66 & 166 & 17 & 96 & 6.3 & 41.0 & 26.55 & 41.6 \\
\hline 10 & PM-17×PM-38 & 62 & 139 & 16 & 93 & 2.6 & 38.4 & 19.93 & 30.7 \\
\hline 11 & PM-20×PM-38 & 56 & 127 & 12 & 89 & 2.3 & 25.0 & 10.44 & 30.3 \\
\hline 12 & PM-16×PM-37 & 59 & 132 & 16 & 90 & 3.9 & 30.5 & 25.70 & 37.2 \\
\hline 13 & PM-28×PM-19 & 62 & 163 & 15 & 93 & 4.0 & 34.7 & 27.22 & 39.2 \\
\hline 14 & PM-21×PM-37 & 68 & 110 & 12 & 95 & 4.8 & 22.8 & 15.40 & 41.4 \\
\hline 15 & PM-31×PM-19 & 63 & 105 & 15 & 93 & 4.3 & 38.7 & 13.80 & 41.0 \\
\hline 16 & PM-28×PM-4 & 65 & 134 & 18 & 92 & 4.6 & 31.6 & 16.69 & 27.3 \\
\hline 17 & PM-38×PM-20 & 64 & 141 & 17 & 95 & 5.5 & 32.0 & 9.76 & 41.9 \\
\hline 18 & PM-10×PM-35 & 60 & 93 & 11 & 96 & 3.8 & 29.6 & 10.15 & 39.4 \\
\hline 19 & PM-22×PM-36 & 63 & 98 & 11 & 96 & 3.6 & 31.3 & 14.48 & 36.6 \\
\hline 20 & PM-36×PM-10 & 64 & 142 & 18 & 95 & 5.3 & 34.7 & 13.56 & 39.3 \\
\hline 21 & PM-20×PM-36 & 65 & 143 & 19 & 95 & 5.5 & 39.0 & 19.13 & 40.6 \\
\hline 22 & PM-17×PM-36 & 68 & 134 & 15 & 95 & 4.3 & 36.8 & 18.73 & 38.1 \\
\hline \multirow[t]{5}{*}{23} & PM-36×PM-20 & 60 & 136 & 19 & 91 & 5.8 & 27.0 & 20.27 & 40.5 \\
\hline & Mean & 63 & 136 & 17 & 93 & 4.6 & 33.8 & 19.55 & 37.8 \\
\hline & Minimum & 56 & 93 & 11 & 89 & 2.3 & 22.8 & 9.76 & 27.3 \\
\hline & Maximum & 69 & 167 & 25 & 96 & 6.3 & 41.0 & 33.58 & 42.5 \\
\hline & S.E. & 0.6 & 1.7 & 1.1 & 0.7 & 0.1 & 0.6 & 1.5 & 0.8 \\
\hline
\end{tabular}


Table.3 Estimation of mean and genetic variability parameters for eight quantitative characters in 23 sunflower hybrids

\begin{tabular}{|c|c|c|c|c|c|c|c|c|}
\hline \multirow{2}{*}{ Sl. No. } & \multirow{2}{*}{ Characters } & \multirow{2}{*}{ Mean \pm SE } & \multicolumn{2}{|c|}{ Range } & \multirow{2}{*}{ PCV $(\%)$} & \multirow{2}{*}{ GCV $(\%)$} & \multirow{2}{*}{$\begin{array}{c}\mathbf{h}^{2}(\mathrm{bs}) \\
(\%)\end{array}$} & \multirow[t]{2}{*}{ GAM (\%) } \\
\hline & & & Minimum & Maximum & & & & \\
\hline 1 & Days to $50 \%$ flowering & $63 \pm 0.6$ & 56 & 69 & 5.6 & 5.3 & 89.7 & 10.3 \\
\hline 2 & Plant height $(\mathrm{cm})$ & $136 \pm 1.7$ & 93 & 167 & 15.9 & 15.7 & 98.2 & 32.1 \\
\hline 3 & Head diameter $(\mathrm{cm})$ & $17 \pm 1.1$ & 11 & 25 & 24.2 & 21.2 & 76.6 & 38.2 \\
\hline 4 & Days to maturity & $93 \pm 0.7$ & 89 & 96 & 2.5 & 2.1 & 70.3 & 3.7 \\
\hline 5 & Test weight $(\mathrm{g})$ & $4.6 \pm 0.1$ & 2.3 & 6.3 & 22.4 & 21.7 & 94.2 & 43.5 \\
\hline 6 & Volume weight $(\mathrm{g} / 100 \mathrm{ml})$ & $33.8 \pm 0.6$ & 22.8 & 41.0 & 14.1 & 13.7 & 94.3 & 27.5 \\
\hline 7 & Seed yield/plant (g) & $19.55 \pm 1.5$ & 9.76 & 33.58 & 34.46 & 31.83 & 85.30 & 60.6 \\
\hline 8 & Oil content $(\%)$ & $37.8 \pm 0.8$ & 30.3 & 42.5 & 10.9 & 10.2 & 87.3 & 19.7 \\
\hline
\end{tabular}

Table.4 Phenotypic correlation coefficient for eight traits in twenty three sunflower hybrids

\begin{tabular}{|c|c|c|c|c|c|c|c|c|c|}
\hline $\begin{array}{l}\text { Sl. } \\
\text { No. }\end{array}$ & Characters & $\begin{array}{c}\text { Days to } \\
\mathbf{5 0 \%} \\
\text { flowering }\end{array}$ & $\begin{array}{c}\text { Plant } \\
\text { height } \\
(\mathbf{c m})\end{array}$ & $\begin{array}{c}\text { Head } \\
\text { diameter } \\
(\mathrm{cm})\end{array}$ & $\begin{array}{l}\text { Days to } \\
\text { maturity }\end{array}$ & $\begin{array}{c}\text { Test } \\
\text { weight }(g)\end{array}$ & $\begin{array}{c}\text { Volume } \\
\text { weight } \\
(\mathrm{g} / \mathbf{1 0 0} \mathrm{ml})\end{array}$ & $\begin{array}{c}\text { Oil } \\
\text { content } \\
(\%)\end{array}$ & $\begin{array}{c}\text { Seed } \\
\text { yield/ } \\
\text { Plant (g) }\end{array}$ \\
\hline 1 & Days to $50 \%$ flowering & 1.0000 & 0.1340 & 0.1646 & $0.5881 * *$ & $0.3023^{*}$ & 0.1475 & 0.1474 & -0.0241 \\
\hline 2 & Plant height $(\mathrm{cm})$ & & 1.0000 & $0.5555^{* *}$ & -0.1168 & $0.4133 * *$ & $0.4482 * *$ & 0.1252 & $0.6449 * *$ \\
\hline 3 & Head diameter $(\mathrm{cm})$ & & & 1.0000 & -0.1648 & $0.5217 * *$ & $0.4257 * *$ & 0.1643 & $0.3827 * *$ \\
\hline 4 & Days to maturity & & & & 1.0000 & $0.2473^{*}$ & 0.1700 & $0.2928 *$ & -0.2047 \\
\hline 5 & Test weight $(\mathrm{g})$ & & & & & 1.0000 & $0.2582 *$ & $0.6285^{* *}$ & $0.2310 *$ \\
\hline 6 & $\begin{array}{l}\text { Volume weight }(\mathrm{g} / 100 \\
\mathrm{ml})\end{array}$ & & & & & & 1.0000 & 0.1610 & $0.4190 * *$ \\
\hline 7 & Oil content $(\%)$ & & & & & & & 1.0000 & 0.0808 \\
\hline 8 & Seed yield/ plant (g) & & & & & & & & 1.0000 \\
\hline
\end{tabular}


Table.5 Genotypic correlation coefficient for eight quantitative traits in twenty three sunflower hybrids

\begin{tabular}{|c|c|c|c|c|c|c|c|c|c|}
\hline $\begin{array}{l}\text { Sl. } \\
\text { No. }\end{array}$ & Characters & $\begin{array}{c}\text { Days to } \\
50 \% \\
\text { flowering } \\
\end{array}$ & $\begin{array}{c}\text { Plant } \\
\text { height } \\
(\mathrm{cm})\end{array}$ & $\begin{array}{c}\text { Head } \\
\text { diameter } \\
(\mathbf{c m})\end{array}$ & $\begin{array}{l}\text { Days to } \\
\text { maturity }\end{array}$ & $\begin{array}{c}\text { Test } \\
\text { weight }(\mathrm{g})\end{array}$ & $\begin{array}{c}\text { Volume } \\
\text { weight } \\
(\mathrm{g} / 100 \mathrm{ml}) \\
\end{array}$ & $\begin{array}{c}\text { Oil } \\
\text { content } \\
(\%)\end{array}$ & $\begin{array}{c}\text { Seed } \\
\text { yield/ } \\
\text { Plant (g) }\end{array}$ \\
\hline 1 & Days to $50 \%$ flowering & 1.0000 & 0.1472 & 0.2084 & $0.8109 * *$ & $0.3222 * *$ & 0.1633 & 0.1569 & -0.0554 \\
\hline 2 & Plant height $(\mathrm{cm})$ & & 1.0000 & $0.6419 * *$ & -0.1381 & $0.4299 * *$ & $0.4657 * *$ & 0.1283 & $0.7122 * *$ \\
\hline 3 & Head diameter $(\mathrm{cm})$ & & & 1.0000 & -0.0842 & $0.5931 * *$ & $0.4877 * *$ & 0.1722 & $0.4917 * *$ \\
\hline 4 & Days to maturity & & & & 1.0000 & $0.2838 *$ & 0.1908 & $0.4187 * *$ & $-0.3329 * *$ \\
\hline 5 & Test weight (g) & & & & & 1.0000 & $0.2787 *$ & $0.7094 * *$ & $0.2373 *$ \\
\hline 6 & $\begin{array}{l}\text { Volume weight }(\mathrm{g} / 100 \\
\mathrm{ml})\end{array}$ & & & & & & 1.0000 & 0.1723 & $0.4597 * *$ \\
\hline 7 & Oil content $(\%)$ & & & & & & & 1.0000 & 0.0888 \\
\hline 8 & Seed yield/ plant (g) & & & & & & & & 1.0000 \\
\hline
\end{tabular}


Fig.1 Heritability $\left(\mathrm{h}^{2}\right)$ and Genetic advance as per cent of mean (GAM) for eight quantitative Traits in hybrids of sunflower

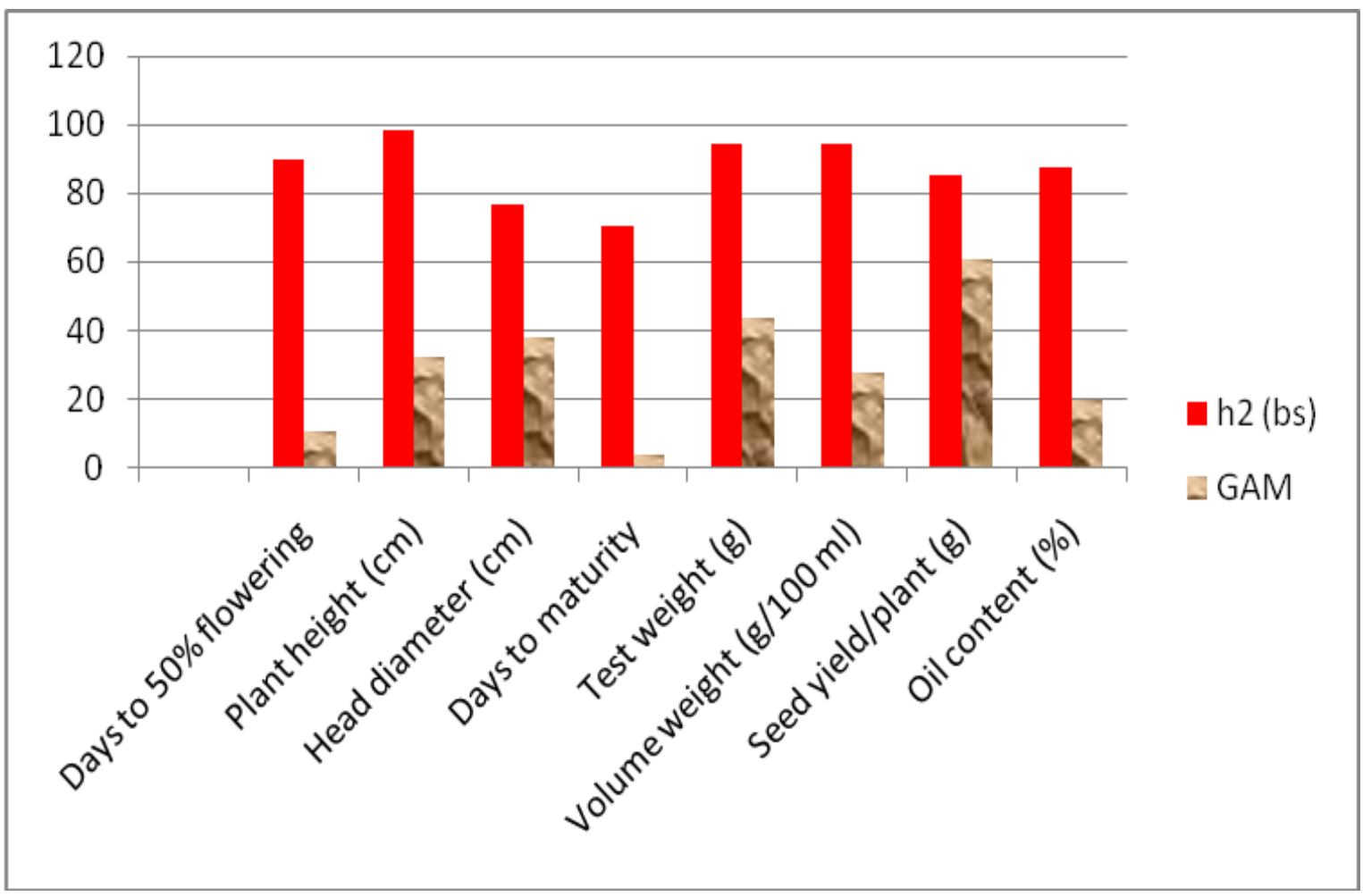

Test weight exhibited highly significant positive correlation with head diameter (0.5217, 0.5931 and $0.4257,0.4877)$, oil content $(0.6285,0.7094)$, plant height (0.4133, 0.4299 and $0.4482,0.4657)$ and significant positive correlation with volume weight $(0.2582,0.2787)$ and seed yield per plant $(0.2310,0.2373)$ both at phenotypic and genotypic level (Tables 4 and 5) for test weight and volume weight, respectively. Similar findings were also made by Uttam et al., (2006) and Kaya et al., (2007). But, Manjunath and Nehru (2003) reported negative correlation between volume weight and seed yield per plant. Whereas significant positive correlation with test weight $(0.2582$, $0.2787)$ and seed yield per plant $(0.4190$, 0.4597) were recorded for volume weight. Similar significant findings were made by Gangappa and Virupakshappa (1994) and negative association seed yield per plant.
These results are in accordance with Senevirtane (2005).

\section{Seed yield per plant (g)}

In majority of cases higher yield and improved input use efficiency is the main goal of breeding programmes. Considerable variation was observed for seed yield per plant among 23 hybrids evaluated, with a minimum of $9.76 \mathrm{~g}$ (PM-38 $\times \mathrm{PM}-20)$ to maximum of $33.58 \mathrm{~g}$ (PM-16×PM-38) with a mean value of $19.55 \mathrm{~g}$ (Table 2). Estimates of PCV and GCV were found to be high with the values 31.8 per cent and 34.5 per cent, respectively with narrow difference between them. High heritability (85.3\%) coupled with high genetic advance as per cent of mean (60.6\%) was observed (Table 3 and Fig. 1). This results are in accordance with vikas et 
al., 2015, Piquemal (1968), Varshney and singh (1977) and Gangappa (1991).

Seed yield per plant recorded highly significant and positive association both at phenotypic and genotypic level with plant height $(0.6449 ; 0.7122)$ followed by volume weight $(0.4190 ; 0.4597)$, head diameter $(0.3827 ; 0.4917)$ and test weight $(0.2310$; 0.2373). Whereas it exhibited negative association with days to $50 \%$ flowering and days to maturity at both phenotypic and genotypic level (Tables 4 and 5). Similar findings were also made by Uttam et al., (2006) and Kaya et al., (2007).

\section{Oil content (\%)}

Breeding for oil yield along with high seed yield is the most important objective in any breeding programme of oil seed crops. Both additive and non-additive gene actions have been proposed to be involved in determining oil content (Nagaraj and Anjani, 1996).

Oil content exhibited mean value of $37.8 \%$ with a maximum of $42.5 \%$ in cross (PM$40 \times \mathrm{PM}-19)$ and minimum of $27.3 \%$ in the cross (PM-28×PM-4) represented in table 2.

Estimates of PCV and GCV were found to be to medium with the values 10.9 per cent and 10.2 per cent, respectively. High heritability $(87.3 \%)$ coupled with moderate genetic advance as per cent 19.7 was observed (Table $3)$. Oil content exhibited highly significant positive correlation with test weight $(0.6285$, 0.7094) and showed significant positive correlation with days to maturity (0.2928) at phenotypic level (Tables 4 and 5). However, it recorded non-significant positive association with seed yield per plant. Hence these two characters are important for oil yield improvement. Mogali (1993) also reported significant positive association of oil yield with seed yield.
Hence, from present investigation it can be inferred that, characters viz., plant height, head diameter, test weight, volume weight and oil content need to be given greater importance during selection for improving seed yield due to strong association between them.

\section{References}

Ashok, S., Lakshminarayana, S. and Kumaresan, D., (2000). Variability studies in sunflower for yield and yield attributes in sunflower. J. Oilseeds Res., 17(2): 239-241.

Bernardo, R., 2002. Breeding for quantitative traits in plants. Stemma Press. Woodbury. MN, USA.

Has, V., 1999. Genetic analysis of some yield components and cernel kernel quality in sweet corn. Romanian Agric. Res., 1112: 9-20.

Burton, G. N. and Devane, E. M., 1953. Estimating heritability in fall fescue (Festuca arundiancea L.) from replicated clonal material. J. Agron., 45:478-481.

Buttar, G.S and H. S. Uppal, 1998. Correlation and path coefficient studies in sunflower. Annals of arid Zone, 37: 83-87.

Cruz, V. G. and R. Dela, 1986. Heterosis and combining ability for yield and yield components in sunflower (Helianthus annuus L.). Crop Sci., 2: 171-174.

Caylak, B. and Emiroglu, 1984. Correlations among some agronomic and exchnological characters in sunflower. Pl. Br. Abst. 1988. Vol. 58, Abst No. 00705.

Chidambaram, S. and Sundaresan, N., 1990, Correlation between yield and yield components in sunflower. Madras Agric. J., 77: 406-407.

Dewey, D.R. and Lu, K.H., 1959. A correlation and path coefficient analysis 
of components of crested wheat grass grain production. J. Agron., 1: 515-518. Epinosa, Z.C., Sevilla, P. E. and Quilantan, V. L., 1992, Charaecterization and evaluation per se of low plant sunflower lones in Mexico. Proceedings of the $13^{\text {th }}$ Intl. Sunflower Conference. 2: 10301036.

Fick, G. N., 1975. Heritability of oil content in sunflower. Crop Sci., 15: 77-78.

Gangappa, E., 1991. Evaluation of sunflower (Helianthus annuus L.) germplasm for yield and yield components. $M . S c$. (Agri.) Thesis, Uni. Agric. Sci., Bangalore. p. 84.

Gangappa, E. and Virupakshappa, K., 1994, Interrelationship of yield components in sunflower (Helianthus annuus L.). Mysore J. Agric. Sci., 28: 1-4.

Gowda, J., 1994, Evaluation of sunflower (Helianthus annuus L.) germplasm for autogamy, yield and yield components. M.Sc. (Agri.) Thesis, Uni. Agric. Sci., Bangalore. p. 109.

Johanson, H. W., Robinson, H. F. and Comstock, H. F., 1955. Estimates of genetic and environmental variability in soybean. J. Agron., 47: 314-318.

Kaya, Y., Evci, G., Durak, S., Pekcan, V. and Gucer, T., 2007. Determining the relationships between yield and yield attributes in sunflower. Turk J. Agric. For., 31: 237-244.

Nehru, S. D. and Manjunath, A., 2003, correlation and path analysis in sunflower (H. annuus L.). Karnataka J. Agric. Sci., 16(1): 39-43.

Nistor, T., Sturzu, R., Nistor, G., Mîrlogeanu, S. and Anghel, J., 2005.Genetic control of the agronomically useful genetic traits in cotton. Romanian Agric. Res., 22: $27-32$

Panse, V.G. (1957). Genetics of quantitative characters in relation to plant breeding. Indian J. Genet., 17: 381-387.
Perumal, P. K. and Rajashekaran, S. (1994). Variability, heritability and genetic advance in sunflower. Madras Agric. J., 81: 92-93.

Gangappa, E., 1991, Evaluation of sunflower (Helianthus annuus L.) germplasm for yield and yield components. $M$. Sc. (Agri.) thesis, UAS, Bangalore, 84pp

Hanson, G. H., Robinson, H. F. and Comstock, R. E., 1956. Biometrical studies of yield in segregating population of Korean lespedeza. $J$. Agron., 48: 267-282.

Lakshamanaiaha, V. H., 1979. Genetic variability and association of morphological characters with seed yield and oil content in sunflower (Helianthus annuus L.). Mysore J. Agric. Sci., 14: 259-261.

Mijic, A., Liovic, I., Zdunic, L., Maric, S., Jeromela, A, M. and Jankulovska, M., 2009. Quantitaitive analysis of oil yield and its components in sunflower. Romanian Agril. Res., 26: 41-46.

Mogali, C. and Suma, 1993. Characterization and evaluation of sunflower (Helianthus annuus L.) germplasm. M.Sc. (Agri.) Thesis, Uni. Agric. Sci., Bangalore. p 97.

Nagaraj, J. G. and Anjani, K., 1996, Seed quality and fatty acid composition of newly developed safflower hybrids and their parents. J. Oilseeds Res., 13(1): 106-108.

Patil, B. R., Rudraradhya, M., Vijaykumar, C. H. M., Basappa, H. and Virupakshapa, K., 1996. Genetic variability in sunflower. J. Oilseeds Res., 13: 157161.

Piquemal, P, G., 1968, Research on the structure of seed yield in sunflower, variations, correlations and heritability of its components. Annls.Amel.Pl, 18:423-446.

Reeve, Y.U. and J.S. Rao, 1981. Path analysis of yield components in black gram. 
Indian J. Agric. Sci., 51: 378-381. Pak. J. Bot., 22(2): 160-167.

Sathisha, V., 1995. Evaluation of sunflower (Helianthus annuus L.) germplasm for yield and yield components. M.Sc. (Agri.) Thesis, Uni. Agric. Sci., Bangalore. p. 93.

Seneviratne, K.G.S., Ganesh, M. and Ranganatha, A.R.G., 2003. Effect of recurrent selection on variability and genetic parameters of yield and yield attributes in sunflower. Annals of the Sri Lanka Dept. of Agric., 5: 227-232.

Singh, R.K., Chaudhary, B.D., 1979. Biometrical methods in quantitative genetic analysis. Kalyani Publishers, New Delhi.

Singh, B., Sachan, J. N. and Singh, D., 1977. Variability and correlation in sunflower (Helianthus annuus L.). Pantanagar $J$. Res., 2: 27-30.

Supriya, S. M., Vikas V. Kulkarni, Shanker goud, I., Lokesha, R. and Govindappa, M. R., 2016, Genetic variability studies for yield and yield components in sunflower (Helianthus annuus L.). Ele. Jr. Pl. Breed., 7(3): 737-741

Teklewold, A., Jayaramaiaha, H. and Gowda, J., 2000. Genetic divergence studies in sunflower (Helianthus annuи L.). Helia, 23: 93-104.
Tariq, M., Idress, G. and Tahir, A., 1992 Genetic variability and correlation studies in sunflower. Sarhad J. Agric., 8: 659-663.

Uttam, K. K., Shorean, R. K., Punia, R. C. and Kumar, R., 2006, Correlation studies of seed yield and seed quality traits in sunflower. Natl. J. Pl. improv, 8: 47-49.

Vanisree, G., Ananthasayana, K. Nagabushanum, G. V. S. and Jagadish, C. A., 1988, Correlation and path analysis in sunflower (Helianthus annuus L.). J. Oilseeds Res., 5: 46-51.

Vikas, K., Shankergoud, I. and Govindappa, M.R., 2015, Evaluation and characterization of sunflower germplasm accessions for quantitative characters. Elect. J. of pl. breed, 6(1): 257-263.

Yusuf, M. A., Rana, M. A. and Akhtar, B., 1985. Evaluation of sunflower cultivars under rainfed conditions. Sarhad $J$. Agric., 5: 73-76.

Varshney, S.K. and Singh, B.S.K., 1977, Correlation and path coefficient analysis in sunflower. Pantanagar J. Res., 2:147149.

Vrânceanu, A. V., 2000. Floarea-soarelui hibrida. Editura Ceres. Bucharest, Romania.

\section{How to cite this article:}

Supriya, S.M., Vikas V. Kulkarni, C.N. Ranganatha and Suresha, P.G. 2017. Quantitative Analysis of Oil Yield and Its Components in Newly Developed Hybrids of Sunflower (Helianthus annuus L.). Int.J.Curr.Microbiol.App.Sci. 6(8): 3088-3098. doi: https://doi.org/10.20546/ijcmas.2017.608.370 